\title{
Neuroaesthetics: Aesthetic in a Naturalistic Perspective of Art Philosophy
}

\author{
By Alberto Marinho Ribas Semeler*
}

On this essay we propose a discussion about the possibility of a biological basis for the aesthetic experience considering some elements of Western aesthetic tradition and recent scientific discoveries in the field of Neuroaesthetics. Thus, we believe it is relevant to review old assumptions that conceived the aesthetic phenomenon from an innatelacquired dimension. This proposal is grounded in traditional naturalistic philosophy point of view.

One evening, I sat Beauty on my knees, and I found her bitter, and I abused her. Arthur Rimbaud, Une Saison en Enfer (in Abuse of Beaty, Danto 2006)

\section{Initial Considerations}

If we restrict the visual direction to wavelength receptors and edge detectors and, subsequently, approach this restriction as a mostly innate factor, we would have to consider the eye as a regulating and decisive dispositive in aesthetic perception. Our brain works in a parallel process. The amount of data is received in multiples forms, for example sensorial data like wavelength receptors from the visual cortex, songs wavelength from the auditory cortex and smell from the olfactory cortex. Each input data is recognized in specialized neuron cell zones in the brain when we see or experience an object of art these signals interchange information simultaneously, each zone with our distinct characteristic, but the final perception works in a synesthetic way. Nevertheless, human experience is something singular which allows the raw specialized data collected by the eyes to be interpreted in an individual way. Therefore, our everyday lives (environmental conditions) and our cultural experiences (social, aesthetic and cognitive-sensorial experiences) end up influencing the way through which we interpret the world.

In Classic Antiquity Aristotle saw aesthetics as intimately related to the organic element, connected to the biological cycles of life. In contemporary thinking his thesis is being approached by different theoretical perspectives that connect biology and aesthetics, or by what we may call "naturalization of the aesthetic experience." This thesis of Aristotelian origin is reinforced by the advent of neuroaesthetics in the 1990s, which emerged as a radicalization of the

* Professor and Researcher, Department of Visual Arts (DAV), Program of Post Graduation of Visual Arts (PPGAV) - Arts Institute, Federal University of Rio Grande do Sul (UFRGS), Brazil. 
naturalistic understanding of aesthetics. In other words, this thesis establishes itself addressing aesthetic experience as a cognitive-physiological act. The advent of computer graphical interfaces technologies at 1990 promotes a revolution in a neurological research. In other sense, this discovery became a big revolution in art and aesthetics questions. The "word" aesthetics was banned in contemporary art reflections and substituted by "word" language influenced in artistic appropriations of Wittgenstein analytical philosophy. First aspect to be highlighted: neuroaesthetics understands art as a by-product of the brain's evolutionary function, which is emphasized once again in the context of scientific research. Such approach implies that mental processes start being investigated taking into account their neurochemistry and cellular physiology. Each day, more scholars have been attempting to understand cultural processes by the prism of neuronal activity. Thus, we have been witnessing a process of naturalization of the human being. So what was formerly interpreted as a purely abstract, immaterial mental action is presently reduced to neurochemical fire neurons in brain activity. This leads to thinking and investigating brain processes and, consequently, the arts from their cellular physiology and neurochemistry.

The naturalization of the aesthetic phenomenon shifts Western artistic tradition which starts being understood from a scientific and technological point of view in a process of feedback. Nevertheless, this contemporary process of naturalization of the aesthetic function does not deny some of the elements of Western tradition. Knowledge was initially seen as merely intuitive or theoretic-philosophical phenomenon can, nevertheless, be denied or legitimized through the monitoring of the visual cortex, reducing the distance between science and art.

\section{Brief Historical Introduction to the Process of Aesthetic Naturalization}

Aesthetic naturalization is an important program in the vast agenda of contemporary discussions on the "naturalization of knowledge." The fast scientific and technological advances of the last decades have made it possible to observe in a non-invasive way the occurrence of the cognitive-cerebral phenomenon. These observations, in turn, have contributed in a decisive way for the rearranging of several fields of investigation, whose main objective is finding physiological (natural) properties for some phenomena in human knowledge. This naturalistic tendency can be detected in the expanding dialogue that has been taking place amongst philosophers, artists, art theorists and neuroscientists. As a consequence new areas of investigation have been created, such as neurophilosophy and neuro-art.

In general terms, the main characteristic of the philosophical branch known as Naturalism consists precisely of an attempt to substantiate epistemology, 
moral, language, and aesthetics by natural properties (submitted or subject to the laws of the natural world). This characteristic by itself allows us to perceive Naturalism in a way that is contrary to the philosophical models, which presuppose the existence of any property that is not subject to the processes and events of the natural world. Thus, any intervention or reaffirmation of "supernatural" elements (self-evident foundational properties, necessary properties which exist by themselves) will be interpreted by Naturalism as illusory and unnecessary.

However, the term naturalism has been employed in a very flexible manner. On one hand, many diverse theoretical positions are frequently denominated naturalistic. On the other hand, it is possible to classify naturalistic stands in two major groups: the reductionist naturalists and the pragmatic naturalists. The former aim at explaining certain phenomena in terms of physio-biological properties and the latter aim at explaining the same phenomena in terms of certain practical regularities (conventional patterns of activity). That in itself permits us to classify both groups in the naturalist category since both of them discard substantialized or "supernatural" conjectures which permeated the classic philosophical discussions.

Thus, the multiple branches of bioaesthetics are robust versions of reductionist naturalism, especially because they aim at investigating the aesthetic experience through biological causal mechanisms. The amplitude of the term naturalism allows us to include theorists of various tendencies such as Gilles Deleuze (rhizomatic model), Semir Seki (biological basis for visual aesthetic pleasure), Ernest Gombrich (behavioural paradigms of biological basis), Ruth Millikan (proper function theory and selection of mechanisms in biological evolution).

This naturalized aesthetics of a pragmatic bias endeavours to show that aesthetic experience is profoundly independent of our linguistic habits. In this sense, the approaches adopted by Arthur Danto and Nelson Goodman can be considered types of pragmatic naturalism (non-reductionist), since at the same time they avoid "supernatural" explanations for the aesthetic experience (refusing substantialized ideas of beauty, sublime, taste), and support the idea that semantic and pragmatic properties are enough to explain the aesthetic phenomenon (a kind of grammaticalization of the experience). We could propose that Wittgenstein's position on the determination of meaning by use would be a type of pragmatic naturalism, since he adopts the conjecture that no element is a priori necessary for the explanation of linguistic practices.

Millikan's ${ }^{1}$ position of human language, in despite of the mainstream of philosophy of language she urges that language function is like others biological phenomena i.e., the human being as natural beings cannot be regarded as outside of the natural world. Her theories invite us to think of language in a

1. Ruth Millikan, Language: a Biological Model (Oxford: Oxford University Press, 2005). 
transgressive way- a pragmatic naturalistic view based on a biological thesis. When the philosophy of language demands that we forsake the relevance of science in the philosophy field, because it does not make sense for the meaning, Millikan has been worked to propose one biological concept of language. In the "Biosemantics," Millikan² research the mechanism of human learning. It involves the "trial and error" process, more frequently that we think - generalization and discrimination, etc. is inscribed in a selection of natural system. The environments make changes in our nervous system learning process - the ends envisioning the final system results.

It is clear that problematic aspects of naturalization projects are far too vast to be addressed here. However, it is important to understand that this thinking tendency is practically irreversible and also dominant in the contemporary context bringing with it a series of new and old problems, most of them relating to methodological areas of art historiography and criticism. If the aesthetic experience originates from causal biological processes (dispositions), than what would be the role of art history? Wouldn't the role of the critic be particularly powerless to "guide" our brain mechanisms in the sense of guaranteeing some measure of aesthetic pleasure?

The French researcher Edmond Couchot, ${ }^{3}$ artist and art critic who studies the relationship between art and technology, in his book La Nature de l'Art: ce que les Sciences Cognitives nous Révèlent sur le Plasir Esthétique analyses the process of naturalization in its several stages. His analysis focuses on cybernetics where the alive and the artificial find common ground. Instead of defining the cognitive process as the mere activation of pre-existing mental representations or as a mirror of the world around us, he understands it as an "incarnate action." The latter would result from multiple sensorimotor experiences with the environment, which would be the real trigger for cognitive processes. For Couchot, Norbert Weimer's cybernetics and Shanon's 1950s information theory were the inspiration for the first cognitivist thesis - the manipulation of symbols according to pre-determined rules. Thus, for him, connectionism is integrated with the notion of information, which lends permanence to the structures of living systems which, in their turn, self-organize towards an internal balance. Interconnecting natural and cultural phenomena, this interpretation of the world of information would imply naturalization. According to Couchot, naturalization is seen as a philosophical branch which aims at defining what it is to be human, at times in a reductionist manner, addressing natural phenomena, submitted to the rules and laws of nature just like any other object in the world. Art, just as any other phenomenon of human culture, understood from a naturalized

2. Ibid., "Biosemantics," Journal of Philosophy 86 (1989): 281-297.

3. Edmond Couchot, La Nature de l'Art: ce que les Sciences Cognitives nous Révèlent sur le Plasir Esthétique (The Nature of Art: What Cognitive Sciences Reveal us on Plasir Aesthetics) (Paris: Hermann Éditeurs, 2012). 
perspective, would be a kind of biological object as a singular means of existence which follows the rules of a particular bioaesthetics.

Other philosophers' will thinks these questions between perceptions and phenomenology. The theories of the French philosopher Merlau-Ponty analyzing a perception as a naturalistic phenomena but, he lies whit a metaphysical position when the humanistic point of view is preponderant and the human conscious is bolded in a perception concurrency that plays an relevant role. The eye is a channel that makes me absent to see my mind fission as Merlau-Ponty. ${ }^{4}$

Another philosopher, Martin Heidegger ${ }^{5}$ sets an important analysis of technology. While he thinks about the evilness of technology the place reserved for art is almost "creationists" negotiating whit a kind of divinity. He thinks of art as an event which something happens in the world with metaphysical transcendental power. The things happen in relationship with your existence in the world. The objects and human beings had an existence between your objecthood and essence. ${ }^{6}$

The conception adopted is this paper about science and technology is "technoscience." Technoscience is thought here as the place of preponderance of the technology over the science i.e., deconstructing the idea of science as a big modern institution superposed over all things, in some way "reversing" Heidegger conception. The aesthetical phenomenon is a physiological experience.

\section{Some Preliminary Questions on Aesthetics}

Continuing our discussion, Raymond Bayer's words are clarifying: Strictly speaking there is no such a thing as the aesthetics of Aristotle, just as there is no such thing as the aesthetics of Plato. But if the whole of Plato's philosophy is aesthetics, Aristotle is no artist. He is a naturalist and he expressed his ideas with the dryness and the precision of a sage. His aesthetic works comprehend, on the one hand, practical opinions on artistic creation, on the other, a chapter on the science of art in which he treated a certain problem in such as way that we always resort to him: a genius explosion of tragedy. Apart from that in Aristotle's metaphysics, it is necessary to look for anything that resembles aesthetics, an implicit aesthetics. ${ }^{7}$

4. Maurice Merleau-Ponty, Résumés de cours. Collège de France 1952-1960 (During summaries. Collège de France 1952-1960) (Paris: Gallimard, 1968).

5. Martin Heidegger, The Question Concerning Technology, and Other Essays (New York: Harper Perennial Modern Classics, 2013).

6. Ibid., Ser e tempo (Being and Time), trans. Fausto Castilho (Campinas, Rio de Janeiro: Editora da UNICAMP, Vozes, 2012).

7. Raymond Bayer, História da Estética (History of Aesthetics), trans. José Saramago (Lisboa: Editorial Estampa, 1995), 47. 
The "implicit" issue that we highlight in a first moment from Bayer's ${ }^{8}$ words refers to a fundamental characteristic of what we would call Aristotle's aesthetics, that is, the unmistakable presence of the Physis and of all the physiology that stems from it. As we know, Physis was something dear to Ancient Greeks and has to do with everything that refers to the body and organic matter. In contrast to the thoughts of Plato, Aristotle believed that the first form of knowledge is empeiria. Translated by experience, the latter focuses on the relationship between the human element and its surroundings through the body. For Aristotle experience is therefore the first form of knowledge and requires the senses and sensations which constitute the body, known as aiesthesis. On that account Bayer reminds us that "the Greek aesthetica is the world of sensations which are opposed to logic."9 Therefore, the etymological origins of the word refer to feelings: the Greek root aisth stems from the verb aisthanomai, which means to feel. Nevertheless, that same root restricts those feelings to physical perceptions, excluding any affectionate or emotional meaning. ${ }^{10}$

Even considering this ambivalence, Classical Antiquity used two basic principles to define art: tekné and mousiké. The notion of tekné implied knowledge and expertise in the use of tools to produce objects. Painting and sculptures were thus included in this domain. The notion of Mousiké was employed to designate the so-called "true" arts: music, dance, and poetry, which according to Plato were divinely inspired. ${ }^{11}$

The term art has its epistemological origins in the term ars, which has its genesis from the translation of the Ancient Greek word tekné, which until de $15^{\text {th }}$ century referred to a set of activities related to expertise and to crafts that were essentially manual. It is nevertheless important to stress that the Ancient Greeks did not make any sort of distinction between art and technique. During the Middle Ages a distinction was established between the liberal arts ${ }^{12}$ which were taught in Universities, the arts of the spirit, the mechanical arts, and the arts for the hand. ${ }^{13}$ Thus from the most ancient cultures to these days it has been difficult to dissociate aesthetics and art. Aesthetics (aesthetica) appears as a term and, therefore, as an autonomous discipline, in the middle of the $18^{\text {th }}$ century with the

8. Ibid.

9. Ibid., 180.

10. Lucia Santaella, Estética de Platão a Peirce (Aesthetics from Plato to Peirce) (São Paulo: Experimento, 1994).

11. Claudia Giannetti, Estética Digital: Sintopia da Arte, a Ciência e a Tecnologia (Digital Aesthetics: Art syntopy, Science and Technology) (Belo Horizonte: C/Arte, 2006).

12. The liberal arts were considered curriculum segments of the Trivium (logic, grammar and rhetoric) and of the Quadrivium (arithmetic, music, geometry, and astronomy).

13. Jean Lacoste, A Filosofia da Arte (A Philosophy of Art), trans. Álvaro Cabral (Rio de Janeiro: Jorge Zahar, 1986). 
publication in 1750 of the book Aesthetica Side Theoria Liberalium Atrium (Aesthetics or Liberal Arts Theory) written by the German philosopher and professor Alexander Gottlieb Baumgarten (1714- 1762). ${ }^{14}$

In The Abuse of Beauty: Aesthetics and the Concept of Art, the North American art critic Arthur Danto ${ }^{15}$ states that the Ancient Greeks did not have in their vocabulary a specific term for what we call art nowadays. Nevertheless, that did not stop them from carrying out discussions on the concept of art and for that reason Greek culture is considered to have been the cradle of the philosophy of art. For Socrates, similitude with life, such as in sculptures and paintings that referred to everyday acts or objects, as well as tragedy, which told of heroic acts and historical episodes, were not part of the concept of art. His ideas were vastly accepted in his time.

Danto $^{16}$ states that the analyses of the platonic concept of art were characterized by a sort of gradation. From that perspective, thinking the concept of art would imply a similitude to life (or mimesis) which was partly a problem connected to taste and its function, therefore representation was merely a part of its definition. This Platonic afterthought on art is ratified by Danto who sees representation merely as a facet of the definition of art. Danto proposes two conditions to art: one of them is semantic (internal and philosophical sense) and the other one pragmatic (involving in some way formal properties with the notion of beauty). Maybe for this reason he is considered one of the forerunners in the separation between philosophy of art and aesthetics, using analytic philosophy as a forceps to ban that which he considers to be toxic properties of art: beauty, the sublime and taste. From Danto's perspective it would not be appropriate to radically deny art the need for a pragmatic condition, according to him we should instead protect it and not justify or even endorse beauty as its pragmatic logic.

For Plato beauty is never incarnate in works of art and exactly for this reason he opposes the "Fine Arts." Nevertheless, one can observe the use of platonic philosophy as a primary reference when dealing with considerations on beauty in the $18^{\text {th }}$ century, when beauty starts being defined from a vintage point of aesthetic pleasure, more or less pure, but radically subjective. Thus, since its birth in the Ancient Greek culture, after obtaining autonomy in the $18^{\text {th }}$ century as a science and as a philosophy of art and of beauty, until its emergence as a precept for $20^{\text {th }}$ century art, aesthetics has generated controversy and offered itself to a myriad of interpretations. As theory and philosophy of beauty it stops making sense from modern art onwards, disconnecting itself from the idea of beauty

14. Alexander Gottlieb Baumgarten, Estética a Lógica da Arte e do Poema (Aesthetic the Art of Logic and Poem), trans. Míriam Sutter Medeiros (Rio de Janeiro: Vozes, 1993).

15. Arthur Danto, The Abuse of Beauty: Aesthetics and the Concept of Art (Chicago: Carus, 2006).

16. Ibid. 
with which it had been invested in the classical sense. On the one hand it starts to pursue ugliness obsessively and, on the other hand, it pursues a metaphysical and linguistic essence for the aesthetic experience.

The notion of beauty starts suffering consecutive "abuses" since the $18^{\text {th }}$ century. Danto states that nowadays beauty has become merely another option for art, losing its place as conditio sine qua non: "Nevertheless, it is not an option for life, but rather a necessary condition, without which we could not live."17 Contemporary art understands beauty as spiritual lust, thus it starts being systematically abused. The first abuse of beauty is of a religious order. It is associated to morals, goodness, truth and religion; thus it would not need to exist in a society which slowly becomes increasingly secular. The second abuse is of a political order. In this case beauty is interpreted as a bourgeois affectation, therefore originating from a state of alienation represented by the ideology of beauty which must be radically opposed. Last, but not least, beauty suffers a philosophical abuse. Aesthetics as a branch of philosophy is associated to the act of beautifying, to futility, to ornamentation and to superficiality, ceasing to have any relevance as a specific branch of philosophy dedicated to the study of beauty. Thus, art must be most and foremost a matter that belongs to philosophy and to language: it must make sense.

Beauty acquires a moral weight being seen merely as one of the many aesthetic qualities, such as truth and goodness, replacing religion in contemporary art. Beauty ceases to be essential to the work of art, since the contemplation of beauty becomes a moral act which must be banished and its removal becomes a political act.

We believe that Danto's line of thought subscribes to contemporary art theories that aim at supporting the aesthetic experience from a linguistic perspective, circumscribing it from a sort of "grammaticalization of the aesthetic experience," i.e., as a phenomenon which allows itself to be described and experienced through language. This interpretation of the artistic object through pure language stems from Socratic thought, which saw human as the measure for all things. It will be opposed by the biologically based aesthetics: Man must conduct a retrospection of himself. ${ }^{18}$ Thus, from a shallow interpretation of Wittgenstein's ideas which, in our point of view, ends up limiting aesthetic experience to a nucleus of pure language, being the latter seen merely through its aspects of pure grammaticality. Consequently, it would eventually work as a logic for "demonizing aesthetics and its derivatives," lending excessive emphasis to language.

17. Ibid., 160.

18. Gilbert Simondon, El modo de existencia de los objetos técnicos (The mode of existence of technical objects) (Buenos Aires: Prometeo, 2008). 


\section{Biology Based Aesthetics}

We can approach aesthetics and its relationship to biology from the most elementary level, i.e., as an organizational force for living structures which precedes and supersedes humanity. Furthermore as an element that makes itself present since the most basic principles of nature's formal organization going as far as more complex levels involving behavioural paradigms. ${ }^{19}$

In the horizon of this relationship between aesthetics and biology (or biology based aesthetics) it is possible to identify two main avenues of investigation, which does not exclude the possibility of hybridization of both.

Let us start at first by briefly contextualizing the mimetic theories which originated from the thought of Aristotle and Plato, thus stressing the differences between the concepts of mimesis in the works of both philosophers.

Plato states that the painter is an imitator of reality, he corrupts reality since he builds his work not from its essence, but from what it appears to be: art is conceived as a degraded copy of the real world; painting distances itself from reality producing a simulacrum or an idol. ${ }^{20}$

From Aristotle's perspective the concept of mimesis derives from a necessary adaptation between art, life, and nature, becoming therefore crucial for that concept. Art tries to imitate the productive faculty of nature, leaving behind its status as a mere copy, becoming a creation where the displacement of the concept of mimesis occurs giving way to the concept of representation. Art does not imitate concepts, ideas, or objects; it operates as an agent which shows itself directed towards formative principles of nature. ${ }^{21}$ It is through this specific characteristic that naturalistic aesthetics stems from Aristotelian thought and develops itself throughout art history in a progressive-intuitive manner. Naturalistic aesthetics have always been present in discussions regarding art sometimes being affirmed, other times being denied - with the aim of establishing a relationship of proximity between natural forces and aesthetic experience.

We consider the philosopher Gilles Deleuze an important representative of the branch that deals with naturalistic art in contemporary philosophy. He addressed concepts which originated from other fields of knowledge such as biology with the aim of amplifying, optimizing, resignifying old philosophical concepts.

There are numerous examples of these operations transposed into philosophical concepts that we could highlight here: ritornello, body without organs, rhizome, cartography, map, movement image, molar molecular, minor

19. Ernst Gombrich, The Sense of Order: a Study in the Psychology of Decorative Art (London: Phaidon, 1984).

20. Lacoste, A Filosofia da Arte.

21. Santaella, Estética de Platão a Peirce. 
literature and major literature, to name just a few. The concept of ritornello, vastly used in the deleuzian philosophy in several occasions throughout his written work, was taken from musical notation. Body without organs is another well-known deleuzian concept which was taken from Antonin Artaud's theatre of cruelty. The way in which Deleuze seizes these concepts from other fields of knowledge, reverting the modus operandi historically adopted by philosophy and with which it secured its epistemological basis, generates methodological outlines which are very unusual within the field of philosophy, granting him with a certain originality, courage and daring.

To a certain extent we can consider the Deleuze's work as being in tune with the process of naturalization of aesthetics. In his work, we find a sort of insistence in approaching men more through the logics of the sensation than of the intellect. That authorizes us to infer that his thought is in alignment with a "biological model" for both human and aesthetic experience. Therefore, at the beginning to $A$ Thousand Plateaus, Deleuze and Guattari use a botanical term, rhizome, to demonstrate how nature can turn out to be wiser than men. It is possible that the use of this term will have other important effects. The term was extracted from botany and placed at the heart of philosophy and it could work as a sort of weed in the garden of well planted and deeply rooted ideas of philosophical thought. Therefore, rhizome would have a political effect, especially because it also has the important task of substituting the verticalized linguistic tree model - and its structure - presenting to philosophy a horizontalized and decentralised "rhizome model," eliminating the possibility of putting men in a position of superiority in relation to other living beings, animals and plants. In the authors' words:

Evolutionary schemas would no longer follow models of arborescent descent going from the least to the most differentiated, but instead a rhizome operating immediately in the heterogeneous and jumping from one already differentiated line to another. ${ }^{22}$

Therefore the rhizome is an attempt of establishing an anti-genealogy, giving way to the non-human becomings of man:

Becoming animal, plant, molecular, becoming zero. [...] What terror haunts Van Gogh's head caught in a becoming- sunflower? In each case style is needed - the writer's syntax, the musician's modes and rhythms, the painter's lines and colors - to raise lived perceptions to the percept and lived affections to the affect. ${ }^{23}$

22. Gilles Deleuze, and Felix Guattari, Mil Platôs: Capitalismo e Esquizofrenia (Thousand DISHES: Capitalism and Schizophrenia) (Vol. 1), trans. Aurélio Guerra Neto, and Célia Pinto Costa (Rio de Janeiro: Editora 34, 1995), 10.

23. Ibid., What is Philosophy? (Chichester: Columbia University Press, 1994), 169. 
The authors refer to perceptions and to affections experienced as being the perception and affections that stick/cling/imprint in our human existence creating a sort of internalised image that gives man roots. It also becomes a personification of the world order, i.e., a whole "psychology" of affections and perceptions which keeps us captive, bound to human identities and to preestablished and ready structures, which stops us from experiencing other ways of existence, different from the already established human models.

It is also in A Thousand Plateaus that Deleuze and Guattari affirm the existence of a sort of wisdom in plants. Man becoming- plant - or becomingvegetal - is his possibility of a different experience that will grant him a possibility of increasing his territory by deterritorialization, a movement that would signal the emergence of a "spread" and deterritorialized existence. Nevertheless, becoming should not be confused with "being similar to," it does not mean a mimetic sort of experience in which a plant, an animal, a vegetable would be imitated, it also does not mean "doing as." Becoming has no connection with dreaming or with the imaginary, it is reality's own consistency, "becoming is a reality." 24 Deleuze and Guattari address a passage from Carlos Juan, in which an Amerindian called Don Juan signalises the path for the protagonist. This path is not merely a description, which is what the anthropologist and scholar wished to receive, but it is a path that should be fully experienced in his own body:

Go first to your old plant and watch carefully the watercourse made by the rain. By now the rain must have carried the seeds far away. Watch the crevices made by the runoff, and from them determine the direction of the flow. Then find the plant that is growing at the farthest point from your plant. All the devil's weed plants that are growing in between are yours. Later [...] you can extend the size of your territory by following the watercourse from each point along the way. ${ }^{25}$

Despite the fact that Deleuze's philosophical thought has a transgressive trait, which is critical towards the system and institutions, his theoretical work remained almost undetected by the field of the arts. Deleuze himself never directed his criticism towards radical aesthetic changes that happened in the art of his time. If on the one hand, he addressed a few elements of contemporary art, on the other hand, he writes extensively on painting and when he addresses contemporary movements the author directs a subtle criticism towards conceptual art. Would Deleuze be establishing a painting as a paradigm for the visual arts? Is he merely a necrophiliac manipulating the

24. François Zourabichvili, O Vocabulário de Deleuze (The Vocabulary Deleuze), trans. André Telles (Rio de Janeiro: Relume Dumará, 2004), 48.

25. Deleuze, and Guattari, A Thousand Plateaus, trans. Brain Massumi (Minneapolis: University of Minessota Press, 1987), 32, 44. 
already dissected corpse of the dead-alive painting predicted by Hegel? Or would he be searching for the new "painting flesh," a reincarnation still capable of affecting and causing "blocks of sensation?"

In another one of Deleuze's books, Francis Bacon: the Logic of Sensation ${ }^{26}$ the author seems to wish to pursue this path towards a "biological model" addressing Francis Bacon's painting. Even the title of the book is a provocation, or better yet, a proposition. In choosing that title, Deleuze leaves behind a hint about which field of experience should we use to place visual arts in: the "logic of sensation," acting in the expression and sensory field. His interpretation is opposed to the rationalist, linguistic and discursive approach to conceptual art. The work of art is a "being of pure sensation," and as a sensation it only exists in/by itself. According to Deleuze there are two ways to overcome figuration: the first one is going towards the abstract (cerebral) form and the second is going towards the figure imprinted on the corporeal or carnal, acting directly from the nervous system, unleashing blocks of sensation, making its physiological strategy evident. According to him, art has the function of preserving; it is the only element in the world which endures, not in the same way that industry does it, adding chemicals, but through a block of percepts/affects sensations. That way, by placing art in the sensory field he is opposing the logic of conceptual art; art as an idea belongs to the order of the brain and the intellect, mostly because it ignores the affects and percepts that are connected to the nervous, to the organic. At least, art takes place in the composition. That which does not compose is not aesthetic and therefore is not art. $^{27}$

It is noticeable in What is Philosophy? Deleuze's attempt to consider an aesthetic that will get as close as possible to a biology based approach in the sense of avoiding the malefic and useless logic in artistic representation. In figural conceptualising, which according to him is a sort of bypass, or a reverse of representation, Deleuze resorts to a physiological strategy. He returns to Cezanne's point of view on sensation proposing that the abstract form acts in the bones through the brain's nervous system, while the figure acts in the sensation and in the flesh.

In choosing Francis Bacon's work, Deleuze surprises and destabilizes the reader. English art critics classified the painter as part of the disgusting art movement, as a "sensation" painter. Bacon uses in his paintings some elements considered as quite traditional in the arts: maintenance of the canvas as a support medium, oil painting technique, illusionism, traditional perspective, use of the portrait and self-portrait (works which are considered as being extremely authorial). Bacon was an artist whose work went against the grain in relation to

26. Deleuze, Francis Bacon: the Logic of Sensation, trans. Daniel W. Smith (London: Continuum, 2003).

27. Deleuze, and Guattari, What is Philosophy? 
his time and his contemporaries, maintaining the painting as a field of experience. His choices marginalized him in relation to more politically "engaged" movements, which never tired of announcing the death of painting. He painted imprisoned figures, confined to rooms or lonely, in general showing suffering and terror, with crumbling bodies, corrupted and manifesting the sensation of pain. According to Deleuze, Bacon's painting is figural because the painter manages to "isolate" the figures stopping the establishment of the empire of representation:

Isolation is thus the simplest means, necessary though not sufficient, to break with representation, to disrupt narration, to escape illustration, to liberate the Figure: to stick to the fact. ${ }^{28}$

This Deleuzian definition of figural on Bacon's artistic work subscribes to the simulacrum category. Art should free itself from representation and from similitude denying any reference to an original, establishing a relationship of difference without, nevertheless, detaching itself from a series or an ensemble; establishing itself in the bodily element of the work, where the virtual element is actualized through art.

Returning to What is philosophy?, written by Deleuze in partnership with Felix Guattari, art appears again as a theme to compose a harmonious triangulation with philosophy and science, a moment in which the authors address each one of them and differentiate their characteristics: thinking through concepts (philosophy), thinking through functions (science), thinking through sensations (art): "the frames of art are no longer scientific coordinates than sensations are concepts, or vice-versa." 29

Abstract art seeks to refine sensation, to dematerialize it by setting out an architectonic plane of composition in which it would become a purely spiritual being, radiant thinking and thought matter, no longer a sensation of sea or tree, but a sensation of the concept of sea or of the concept of tree.

According to Deleuze and Guattari things would have happened somewhat differently in relation to conceptual art:

Conceptual art seeks an opposite dematerialization through generalization by installing a sufficiently neutralized plane of composition (the catalogue that brings together works not displayed, the ground covered by its own map, disused spaces without architecture, the flatbed plane) so that everything takes on a value of sensation reproducible to infinity: things, images or clichés, propositions - a thing, its photograph on the same scale and in the same place, its dictionary definition. ${ }^{30}$

28. Deleuze, Francis Bacon: the Logic of Sensation, 3.

29. Ibid., 202.

30. Ibid., 198. 
Deleuze and Guattari are both adamant in stating that conceptual art cannot reach sensation, neither can concept, mostly because its plane of composition happens in a merely informative way and "sensation depends upon the simple "opinion" of a spectator who determines whether or not to "materialize" the sensation, that is to say, decides whether or not it is art." 31

The French scholar Paul Ardene ${ }^{32}$ followed in Deleuze's footsteps proposing a sort of art which he calls contextual, in which the artist must represent his work in situ, seeking a close connection with the local ecology, whether it is of an urban order and potentializes micropolitics, or even literally placed in a natural environment - art is often a hostage of culture and its apparatus, nature allows art to disconnect from those principles offering in turn an unlimited context.

Deleuze and his interpreters go against the grain when they think about matters that refer to philosophy and, therefore, to art. They elaborate their concepts in an exogenous manner to debate matters that belong to philosophy of art. Such is the case with the appropriation and use of scientific terms such as rhizome or molar versus molecular. Some examples of this contrary movement would be some of the contemporary endogenous interpretations of art that use Wittgenstein's philosophy of language as a starting point. The latter interprets the world from what this branch of philosophy considers essential, i.e., language.

The break with this perception can be viewed in feminist psychoanalyst Julia Kristeva ${ }^{33}$ that sees, in horror, one universal drive for subjectivation. Fear is an oldest bio-drive that mobilizes sensations of repulse and produces an aesthetical experience. "I was afraid to be bitten or to bite" this question initiates a rebound movement of sensation in the art - the abject art. The abject was 1980 movement in art that recovers the importance of corporal sensations and feelings in art i.e., repulse is a corporal sensation that link viewer at art.

We can also cite the biology based artistic experience originated from progressive scientific advances which are interested in understanding how the complex cortical processes involved in the mechanisms of perception, construction, and sensation of image occur. Currently, these investigations are being potentialized by the development of digital visual technology, through graphic interfaces of visualization in computers, making it possible for scientists to observe and investigate perceptive phenomena in real time, in

31. Ibid.

32. Paul Ardenne, Un Arte Contextual: Creación Artística en Medio Urbano, en Situación, de Intervencion, de Participación (A Contextual Art: Artistic Creation in the Urban, in situation, intervention Participation), trans. Françoise Mallier (Murcia: Cendeac, 2006).

33. Julia Kristeva, Powers of Horror: an Essay on Abjection (New York: Columbia University, 1982). 
a non- invasive way, as happens with tests such as PET (positron emission tomography), and fMRI (functional magnetic resonance imaging).

In Neuroarthistory: from Aristotle and Pliny to Baxandall and Zeki, John Onians, a British art historian, reviewed the history of art taking into account recent scientific discoveries about the way in which the visual cortex operates. Onians reinterpreted art theory considering scientific discoveries. An example would be the way in which he associated mimetic theory in art and a specific group of neurones, the mirror neurones, discovered by the Italian neurophysiologist Giacomo Rizzolati between the 1980s and the 1990s, allowing the pure observation of the learning process. Neurones present in the premotor cortex demonstrate how we learn. Through imitative processes, even if we do not understand the meaning of the actions we carry out, or without performing any movement. When we observe someone performing any task we activate in ourselves the same area of the cerebral cortex. ${ }^{34}$

The British scientist Semir Zeki, who created neuroaesthetics as a new branch of aesthetics, is seeking a biological basis to the scientific understanding of visual aesthetic pleasure. Zeki taught neurobiology at University College London in the 1970s and he was the first scholar to apply scientific knowledge originated from neurobiology, neuroanatomy and such to the understanding of art. Thus, he became an international reference in the study and research of the visual brain. It can be said that neuroaesthetic, to an extent, addresses some matters from Aristotelian aesthetics, which associated mimesis to pleasure, investigating cerebral mechanisms involved in aesthetic pleasure. ${ }^{35}$

In Inner Vision: an Exploration of Art and the Brain, essay published in 1999, Zeki addresses the results of his investigation on the brain, inferring that to a large extent the function of art and the function of the visual brain are the same. Visual arts are a function of the visual brain - every visual art is expressed by the brain and, therefore, follows its laws. ${ }^{36}$ Zeki considers modern painters as a sort of neurologist, since when they produce their work they use singular pictorial investigations to achieve the desired effect and through that process they find personal pleasure and, thus, they gratify their brain. Finding pleasure in the production of their pictorial work results in gratification for themselves and for their spectators. And when they find visual brain pleasure in themselves and in other brains, they end up revealing most of the laws of neural organization as well as brain paths to obtain cerebral gratification, even if they completely ignore the details involved in this process or even ignore its existence. ${ }^{37}$

34. John Onians, Neuroarthistory: from Aristotele and Pliny to Baxandall and Zeki (London: Yale, 2007).

35. Ibid.

36. Semir Zeki, A Vision of the Brain (London: Blackwell, 1993), 52.

37. Ibid., Inner Vision: an Exploration of Art and the Brain (London: Oxford, 1999). 
From the perspective of Zeki's theory, human beings see so that they can know the world. Some of the species alive today have very little success in that enterprise, and their environments are defined by their rudimentary visual mechanisms, which makes their survival very difficult from an evolutionary point of view. Despite the fact that vision is not considered the only means for the acquisition of knowledge, some categories of knowledge such as the recognition of facial expressions or of a coloured surface are not apprehended without vision. Thus, it can be inferred that the brain would be more interested in constant elements, the permanence of properties inherent to objects and surfaces of the outer world. The sense of vision is an active process in which the brain tends to discard changes extracting whatever is necessary so that it can categorize objects in the environment. An example would be the constancy of colour which allows us to visualise objects under various conditions, angles and distances. An object should be categorized according to its colour, and for that reason we are capable of distinguishing a ripe fruit from an unripe one. Even with the occurrence of change in the environmental light objects will remain recognizable due to colour constancy. During the process of evolution of the human species, colour perception allowed us to experience an evolution that was significantly superior in relation to other primates. This evolution made it possible for us to recognize food in several shades and consequently permitted us to enrich our diet with nutrients, which in turn allowed us to evolve the cortical region of our brain. Zeki's research reunites tradition and innovation in the sciences and in the arts, giving back to visual experience the importance it had lost in some contemporary art trends. In that sense, neuroaesthetics as a research field is not restricted to the arts. That happens especially because neuroaesthetics approaches the aesthetic phenomenon as a function that evokes psychic states involving perception, sensoriality, cognitive and emotional states in both the creator and observer, taking into account that these states have a neurobiological basis.

\section{Bibliography}

Ardenne, Paul. Un Arte Contextual: Creación Artística en Medio Urbano, en Situación, de Intervencion, de Participación (A Contextual Art: Artistic Creation in the Urban, in situation, intervention Participation). Translated by Françoise Mallier. Murcia: Cendeac, 2006.

Baumgarten, Alexander Gottlieb. Estética a Lógica da Arte e do Poema (Aesthetic the Art of Logic and Poem). Translated by Míriam Sutter Medeiros. Rio de Janeiro: Vozes, 1993.

Bayer, Raymond. História da Estética (History of Aesthetics). translated by José Saramago. Lisboa: Editorial Estampa, 1995. 
Couchot, Edmond. La Nature de l'Art: ce que les Sciences Cognitives nous Révèlent sur le Plasir Esthétique (The Nature of Art: What Cognitive Sciences Reveal us on Plasir Aesthetics). Paris: Hermann Éditeurs, 2012.

Danto, Arthur. The Abuse of Beauty: Aesthetics and the Concept of Art. Chicago: Carus, 2006.

Deleuze, Gilles. Francis Bacon: the Logic of Sensation. Translated by Daniel W. Smith. London: Continuum, 2003.

Deleuze, Gilles, and Guattari, Felix. A Thousand Plateaus. Translated by Brain Massumi. Minneapolis: University of Minessota Press, 1987. . Mil Platôs: Capitalismo e Esquizofrenia (Thousand DISHES: Capitalism and Schizophrenia) (Vol. 1). Translated by Aurélio Guerra Neto, and Célia Pinto Costa. Rio de Janeiro: Editora 34, 1995. What is Philosophy?. Chichester: Columbia University Press, 1994.

Giannetti, Claudia. Estética Digital: Sintopia da Arte, a Ciência e a Tecnologia (Digital Aesthetics: Art syntopy, Science and Technology). Belo Horizonte: C/Arte, 2006.

Gombrich, Ernst. The Sense of Order: a Study in the Psychology of Decorative Art. London: Phaidon, 1984.

Heidegger, Martin. The Question Concerning Technology, and Other Essays. New York: Harper Perennial Modern Classics, 2013.

__. Ser e tempo (Being and Time), trans. Fausto Castilho. Campinas, Rio de Janeiro: Editora da UNICAMP, Vozes, 2012.

Kristeva, Julia. Powers of Horror: an Essay on Abjection. New York: Columbia University, 1982.

Lacoste, Jean. A Filosofia da Arte (A Philosophy of Art). Translated by Álvaro Cabral. Rio de Janeiro: Jorge Zahar, 1986.

Merleau-Ponty, Maurice. Résumés de cours. Collège de France 1952-1960 (During summaries. Collège de France 1952-1960). Paris: Gallimard, 1968.

Millikan, Ruth. Language: a Biological Model. Oxford: Oxford University Press, 2005.

"Biosemantics." Journal of Philosophy 86 (1989): 281-297.

Onians, John. Neuroarthistory: from Aristotele and Pliny to Baxandall and Zeki. London: Yale, 2007.

Santaella, Lucia. Estética de Platão a Peirce (Aesthetics from Plato to Peirce). São Paulo: Experimento, 1994.

Simondon, Gilbert. El modo de existencia de los objetos técnicos (The mode of existence of technical objects). Buenos Aires: Prometeo, 2008.

Zeki, Semir. A Vision of the Brain. London: Blackwell, 1993. . Inner Vision: an Exploration of Art and the Brain. London: Oxford, 1999.

Zourabichvili, François. O Vocabulário de Deleuze (The Vocabulary Deleuze). Translated by André Telles. Rio de Janeiro: Relume Dumará, 2004. 
